\title{
Sublethal Toxic Effects and Induction of Glutathione S-transferase by Short Chain Chlorinated Paraffins (SCCPs) and C-12 alkane (dodecane) in Xenopus laevis Frog Embryos
}

\author{
B. BURÝŠKOVÁ ${ }^{1,2 *}$, L. BLÁHA ${ }^{1,2}$, D. VRŠKOVÁ ${ }^{3}$, K. ŠIMKOVÁ ${ }^{1}$, B. MARŠÁLEK ${ }^{1,2}$ \\ ${ }^{1}$ RECETOX (Research Center for Environmental Chemistry and Ecotoxicology), Masaryk University, \\ Kamenice 3, CZ 62500 Brno, Czech Republic \\ ${ }^{2}$ Institute of Botany, Czech Academy of Science, Květná 8, CZ 60365 Brno, Czech Republic \\ ${ }^{3}$ Department of Biology and Wildlife Diseases, University of Veterinary and Pharmaceutical Sciences, \\ Palackého 1-3, CZ 61242 Brno, Czech Republic
}

Received March 17, 2005

Accepted March 16, 2006

\begin{abstract}
Burýšková B., L. Bláha, D. Vršková, K. Šimková, B. Maršálek: Sublethal Toxic Effects and Induction of Gutathione S-transferase by Short chain Chlorinated Paraffins (SCCPs) and C-12 alkane (dodecane) in Xenopus laevis Frog Embryos. Acta Vet. Brno 2006: 75: 115-122.

Short chain chlorinated paraffins (SCCPs) are important industrial chemicals with high persistence in the environment but poorly characterized ecotoxicological effects. We studied embryotoxic effects of commercial mixture of SCCP (carbon length C-12, 56\% of chlorine; CP5612) and non-chlorinated n-alkane (dodecane, C-12) in the 96h Frog Embryo Teratogenesis Assay - Xenopus (FETAX). Only weak lethal effects were observed for both substances (the highest tested concentration $500 \mathrm{mg} / \mathrm{L}$ of both chemicals caused up to $11 \%$ mortality). On the other hand, we observed developmental malformations and reduced embryo growth at $5 \mathrm{mg} / \mathrm{l}$ and higher concentrations. However, the effects were not related to chlorination pattern as both SCCPs and dodecane induced qualitatively similar effects. SCCPs also significantly induced phase II detoxification enzyme glutathione S-transferase (GST) in Xenopus laevis embryos even at 0.5 $\mathrm{mg} / \mathrm{L}$, and this biomarker might be used as another early warning of chronic toxic effects. Our results newly indicate significant developmental toxicity of both SCCPs and n-dodecane to aquatic organisms along with inductions of specific biochemical toxicity mechanisms.
\end{abstract}

Developmental toxicity, FETAX, frog embryo, SCCPs, glutathione S-transferase

Short chain chlorinated paraffins (SCCPs) are chlorinated derivatives of n-alkanes with carbon chain length ranging from 10 to 13 , and a chlorine content between $30 \%$ and $70 \%$, by weight. They are important industrial chemicals with the main applications as metal working fluids, plasticizers and flame retardants in paints, rubber and textiles, coatings and sealants. SCCPs have low vapour pressure $\left(2.8 \times 10^{-7}\right.$ to $\left.0.5 \mathrm{~Pa}\right)$, which is in the range of some persistent organic pollutants (POPs) known to undergo long-range atmospheric transport. SCCPs have low solubility in water (up to $994 \mu \mathrm{g} / \mathrm{l}$; Drouillard et al. 1998), and due to extremely low biodegradability (S tre et et al. 1983) and high hydrophobicity (Tomy et al. 1998) they concentrate in organic matter-rich matrices such as sediments and soils (Ballschmiter 1994; Drouillard et al. 1998) and they also tend to bioaccumulate in living organisms (Fisk et al. 1996).

Available monitoring data document widespread contamination of water, sediments, aquatic and terrestrial organisms and even commercial foods by SCCP residues (Government of Canada 1993; St ejn arova et al. 2005). Concentrations in the U.K. marine and fresh waters remote from industry ranged $0.1-1 \mu \mathrm{g} / \mathrm{l}$, but increased levels are expected in urban or industrial areas (Campbell and McConnell 1980). Bioaccumulation in marine mammals has been documented by Tomy et al. (2000) who reported concentrations of SCCPs ranging 110-770 $\mathrm{ng} / \mathrm{g}$ wet weight in the blubber of ringed seal

Address for correspondence:

Blanka Burýšková, MSc.

RECETOX, MU Brno

Kamenice 126/3

62500 Brno, Czech Republic
Phone: +420549493515

Fax: +420549492840

E-mail: buryskova@recetox.muni.cz

http://www.vfu.cz/acta-vet/actavet.htm 
(Phoca hispida), beluga whales (Delphinapterus leucas), and walrus (Odobenus rosmarus). Although the EU Directive 2002/45/EC restricts the use of SCCPs in Europe (especially in metal working fluids and leather finishing products), SCCPs remain of environmental relevance and scientific interest. SCCPs are listed as priority hazardous substances within the Water Framework Directive of EU (EU Directive 2000/60/EC), and are considered "toxic" pursuant to Decision 1998/2, Paragraph 1(b) of the UNECE POPs Protocol.

In spite of the wide use and distribution of SCCPs, there are gaps in understanding their toxicity and ecotoxicity. Professional exposures as well as secondary poisoning in the food chain might be of special concern to human health. Some of the documented SCCPs effects with laboratory animals include hepatocellular hypertrophy, increase of thyroid weight and follicular cell hypertrophy, depletion of thyroxin (T4) and inductions of uridin diphosphate glucuronosyl transferase - UDPGT (European Commission 2000).

Available ecotoxicity data indicate low acute lethality of SCCPs (Thompson and Madeley 1983a; Linden et al. 1979) but severe negative effects in aquatic biota were observed after chronic exposures (Bengts on and Ofstad 1982; Madeley and Maddock 1983a). For example in fish, significant decrease in larval growth of sheepshead minnow (Cyprinodon variegatus) was recorded after 32 day exposure to SCCPs (Hill and Maddock 1983b). Lowest observable effects concentrations (LOECs) in the embryolarval assays with Japanese medaka (Oryzias latipes) ranged from 55 to $460 \mu \mathrm{g} / \mathrm{l}$ (F is k et al. 1999). Cooley et al. (2001) reported behavioural effects (absent startle response and reduced feeding) and histopathological changes in thyroid gland and liver of juvenile rainbow trout exposed dietary.

However, there is a substantial lack of data on SCCPs' effects on other organisms than fish such as amphibians, which are of particular concern due to a world-wide population decline (Kiesecker et al. 2001). The standardized 96h assay Frog Embryo Teratogenesis Assay-Xenopus (FETAX) is often used as a screening test to determine embryotoxicity and the teratogenic risk of chemical agents (Dumont et al. 1983). The aim of this study was to provide first experimental data on sublethal toxic effects of SCCPs (CP-12 mixture, $56 \%$ of chlorine) to frog embryos. In order to evaluate the role of chlorination in toxicity, we compared the effects of SCCPs with parent non-chlorinated n-alkane (dodecane, C-12). We studied mortality, malformations and growth inhibitions as well as biochemical changes (activities of glutathione S-transferase, GST) in Xenopus laevis embryos exposed to tested chemicals. Induction of GST activity is often used as a biomarker of chronic toxic effects of organic xenobiotics (Living st one 1998). In this study we newly describe significant nonlethal effects of SCCPs and n-dodecane to frog embryos, and we demonstrate methodological improvement of the FETAX by determining GST as an early warning biomarker of non-lethal toxicity.

\section{Materials and Methods}

Commercial mixture of SCCPs, CP56-12 (56\% of chlorine by weight, chain length C12) was supplied by Novácke Chemicke Závody, Slovakia, n-dodecane ( $99 \%$ purity) was from Sigma (Sigma-Aldrich, Prague). Reduced glutathione (GSH) and 1-chloro-2,4 dinitrobenzene (CDNB) were purchased from Sigma (SigmaAldrich, Prague). Other chemicals used for preparation of FETAX exposure media as well as solvent (dimethylsulfoxide, DMSO) were of p.a. quality.

Frog embryos were obtained from adult pairs of Xenopus laevis injected with human chorionic gonadotropin (HCG; N.V. Organon, Oss, Holland) in the dorsal lymph sac (females: 300 IU; males: 150 IU). Amplexus normally ensued within 2 to $6 \mathrm{~h}$ and the deposition of eggs took place from 9 to $12 \mathrm{~h}$ after injection. Embryo tests were conducted using the standard guide for conducting the Frog Embryo Teratogenesis Assay - Xenopus (ASTM 1998). Only mid-blastula (stage 8) to early gastrula (stage 11) embryos (Nieuwkoop and Faber 1994) were selected for testing.

Groups of 25 embryos were randomly placed in covered 60-mm plastic Petri dishes in $10 \mathrm{ml}$ of standard FETAX solution (625 mg NaCl, $96 \mathrm{mg} \mathrm{NaHCO} 3,30 \mathrm{mg} \mathrm{KCl}, 15 \mathrm{mg} \mathrm{CaCl}, 60 \mathrm{mg} \mathrm{CaSO} \cdot 2 \mathrm{H}_{2} \mathrm{O}$, and $75 \mathrm{mg} \mathrm{MgSO}_{4}$ per litre of distilled water, $\mathrm{pH}$ was 7.6-7.9). Stock solutions of tested compounds and appropriate dilutions were 
prepared in DMSO and $50 \mu \mathrm{l}$ per $10 \mathrm{ml}$ of exposure media were added $(0.5 \% \mathrm{v} / \mathrm{v}$ final concentration of solvent), final nominal tested concentration ranged $0.2-500 \mathrm{mg} / 1$. Each concentration was tested in two parallels, four dishes with embryos in FETAX solution only served as controls. The assay was performed at $23{ }^{\circ} \mathrm{C} \pm 1{ }^{\circ} \mathrm{C}$ for $96 \mathrm{~h}$, exposure solutions were changed every $24 \mathrm{~h}$ and dead embryos were recorded and removed. Embryos were also examined for behavioral abnormalities such as twisting. At the end of the assay $(96 \mathrm{~h})$ surviving embryos were fixed in formaldehyde $(3 \% \mathrm{v} / \mathrm{v})$ and assessed for morphological abnormalities under a dissecting microscope, and the head-tail length of fixed embryos was determined. For the biochemical determinations, embryos were frozen at $-80{ }^{\circ} \mathrm{C}$ until further processing.

Glutathione S-transferase activity (GST) was measured spectrophotometrically using 1-chloro-2,4 dinitrobenzene (CDNB) as a substrate, according to the method of Habig et al. (1974). Specific activity was expressed as nanomoles of formed product per minute per milligram protein. The protein concentration was determined according to the method of Lowry (1951).

Independent experiments using two different pairs of adults were performed. Since $50 \%$ lethality was not observed even at the highest tested doses, concentrations causing $25 \%$ effect - $\mathrm{LC}_{25}$ (for lethality) and $\mathrm{EC}_{25}$ (for malformations) - were estimated as endpoints using a probit model. Differences among the total embryo lengths were evaluated by ANOVA and LSD post-test, and the MCIG (minimal concentration significantly inhibiting the growth) was estimated. Differences in frequencies were compared by chi-square test. The $95 \%$ confidence intervals were used as the measure of variability. The modified teratogenic index (TI) was calculated as a ratio of $\mathrm{LC}_{25}$ and $\mathrm{EC}_{25}$ for tested compounds.

\section{Results}

Our study revealed low acute lethality of both SCCP and dodecane to frog embryos. The highest tested concentrations $(500 \mathrm{mg} / \mathrm{l})$ resulted in weak $11 \%$ mortality (Table 1$)$. On the

Table 1. Effects of short chain chlorinated paraffins (mixture C-12, 56\% chlorine) and n-dodecane on the survival and growth of Xenopus laevis embryos in 96h FETAX

\begin{tabular}{|cccccccc|}
\hline & & \multicolumn{3}{c}{ \% mortality } & \multicolumn{3}{c|}{ head-tail length (mm) } \\
\hline & Concentration(mg/l) & $\mathrm{N}$ & Mean & SD & Mean & SD & P \\
\hline SCCPs & 500 & 40 & 11.00 & 8.49 & 8.18 & 0.64 & $<0.001^{*}$ \\
& 50 & 40 & 11.50 & 9.19 & 8.85 & 0.94 & $0.0487^{*}$ \\
& 5 & 40 & 5.00 & 0 & 9.08 & 0.45 & $>0.05$ \\
& 1 & 40 & 4.50 & 6.36 & 9.01 & 0.62 & $>0.05$ \\
C12 & 0.2 & 40 & 2.50 & 3.54 & 9.21 & 0.48 & $>0.05$ \\
& 500 & 40 & 7.00 & 2.83 & 8.87 & 0.73 & $0.025^{*}$ \\
& 50 & 40 & 12.50 & 2.12 & 9.03 & 0.37 & $>0.05$ \\
& 5 & 40 & 10.50 & 3.54 & 9.14 & 0.72 & $>0.05$ \\
& 1 & 40 & 2.00 & 2.83 & 9.41 & 0.43 & $>0.05$ \\
control & 0.2 & 40 & 0 & 0 & 9.15 & 0.41 & $>0.05$ \\
\end{tabular}

Asterisks $(*)$ indicate statistically significant difference from the control (ANOVA plus LSD post-test)

other hand, both non-chlorinated n-dodecane and polychlorinated paraffins induced morphological malformations at concentrations as low as $5 \mathrm{mg} / \mathrm{l}$ (Fig. 1). More than $50 \%$ of embryos were malformed at the highest tested concentration of SCCPs, non-chlorinated dodecane induced malformations in about $30 \%$ of surviving embryos. Oedema, abnormal gut development, adverse curving of backbone and microphthalmia were the most often observed malformations at both substances (Plate VI, Fig. 2). The differences between the mean head-tail length of controls and exposed embryos were statistically evaluated and estimated experimental minimum concentrations inhibiting growth (MCIG) were 50 and $500 \mathrm{mg} / \mathrm{l}$ for SCCPs and n-dodecane, respectively (Table 1). Animals exposed to SCCP ( $\geq$ $50 \mathrm{mg} / \mathrm{l})$ and $\mathrm{n}$-dodecane $(500 \mathrm{mg} / \mathrm{l})$ exhibited also apparent changes in behavior as noncoordinated twisting and writhing of embryos after 72 and $96 \mathrm{~h}$ of exposure. Newly introduced assessment of GST in frog embryos revealed inductions of enzyme activity in all tested concentrations (Fig. 3).

To evaluate teratogenic risk, modified calculation of TI was used. For SCCP, the 


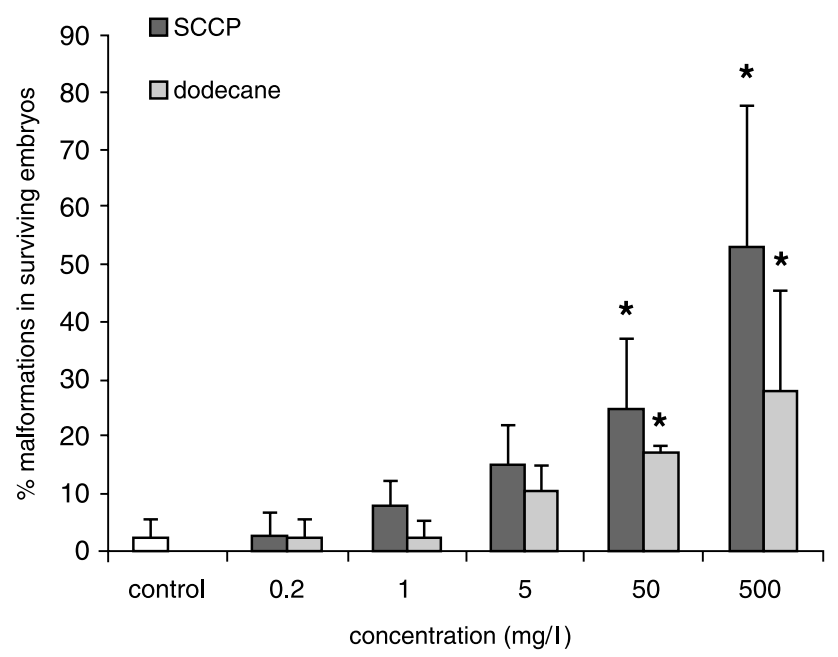

Fig. 1. Effects of SCCPs and n-alkane on development of frog embryos. Bars represent means \pm standard deviation of mean of independent experiments each performed in two parallels. Asterisks (*) indicate statistically significant increase in malformations in comparison with the control (mean $\pm \mathrm{SD}$; Chi-square, $P<0.01$ )

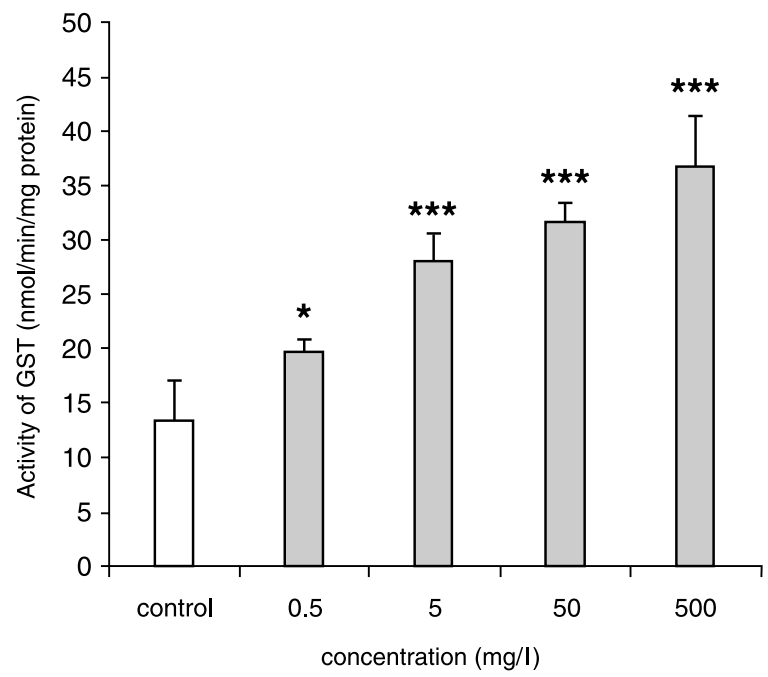

Fig. 3. Activity of glutathione S-transferase (GST) in tissue homogenate from Xenopus laevis after $96 \mathrm{~h}$ exposure to commercial mixture of SCCP (CP56-12). Asterisks $(*)$ indicate statistically significant differences from the control (mean $\pm \mathrm{SD}$; ANOVA, LSD-test, ${ }^{*} P<0.05 ; * * * P<0.001$ )

malformation $\mathrm{EC}_{25}$ as well as MCIG were $50 \mathrm{mg} / 1$. Comparable lethal effect ( $25 \%$ mortality, $\mathrm{LC}_{25}$ ) was not observed even at the 10-times higher concentration $(500 \mathrm{mg} / \mathrm{l})$. Therefore, teratogenic index for SCCPs $\left(\mathrm{TI}=\mathrm{LC}_{25} / \mathrm{EC}_{25}\right)$ could be expressed as $\mathrm{TI}>10$. In case of n-dodecane, EC25 and MCIG corresponded to the highest tested concentration $(500 \mathrm{mg} / \mathrm{l})$ in which only minor lethality was observed (7\%) and evaluation of TI was not possible. 


\section{Discussion}

The results presented in this report show significant growth inhibition and increase in numbers of malformed frog embryos exposed to both chlorinated technical mixture of SCCPs ( $56 \%$ chlorine by weight) and non-chlorinated parent compound (n-dodecane). Our study indicates significant embryotoxic and teratogenic potential of SCCPs (estimated TI $>10$ ) as TI $>1.5$ is considered significantly teratogenic in standardized FETAX protocol (ASTM 1998). To our best knowledge, there is surprisingly limited information on the developmental toxicity of these priority persistent compounds to aquatic biota. Our investigations with frog embryos complement the previous study of F is k et al. (1999) who evaluated toxicity of C-10-, C-11-, C-12-, and C-14- polychlorinated alkanes (40-70\% of chlorine) to embryos of Japanese medaka fish (Oryzias latipes). F is k et al. (1999) reported 20 day LOECs ranging 55 to $460 \mu \mathrm{g} / \mathrm{l}$. The differences in effective concentrations (LOEC $50 \mathrm{mg} / \mathrm{l}$ in our study) can be explained either by prolonged exposures in the study of Fisk et al. (1999) but also by interspecies variability as the comparative study of S parling et al. (2000) demonstrated relatively lower sensitivity of Xenopus laevis embryos to various xenobiotics.

Other studies documented significant ecotoxicity of SCCPs to aquatic biota. In rainbow trout, 48 and 96 hour $\mathrm{LC}_{50}$ were above $100 \mathrm{mg} / \mathrm{l}$ but chronic effects were observed (60 day $\mathrm{LC}_{50}=0.34 \mathrm{mg} / \mathrm{l}$ and NOEC $<0.040 \mathrm{mg} / \mathrm{l}$; Madeley and Maddock 1983a). Also aquatic invertebrates seem to be sensitive to SCCPs as 21 day tests with Daphnia magna showed $\mathrm{EC}_{50}$ values ranging 0.101-0.228 mg/l (European Commission 2000; Thomps on and Madeley 1983a). Significant effects of SCCPs were also observed at both acute and chronic exposures with mysid shrimp Mysidopsis bahia (96 hour mortality LC $_{50}$ ranged 14.1-15.5 $\mu \mathrm{g} / 1$, chronic 28-day LOEC = 7.3 $\mu \mathrm{g} / 1$; Thomps on and Madeley 1983d), and significant growth reductions were recorded in common mussel (Mytilus edulis) exposed to $\operatorname{SCCP}(58 \% \mathrm{Cl})$ at $9.3 \mu \mathrm{g} / 1$ (Thomp son and Shillabeer 1983$)$.

In spite of existing toxicological and ecotoxicological studies with SCCPs, there is only limited experimental evidence on possible biochemical toxicity mechanisms of these compounds. The thyroid and liver are target organs in repeated dose studies with rats and mice. The liver damage is associated with peroxisome proliferation, whereas the thyroid effects are correlated to altered thyroid hormone status and uridin diphosphate glucuronosyl transferase (UDPGT) induction (Brucker-Davis 1998; Wyatt et al. 1993; European Commission 2000). Recent study also showed comparable effects in fish (Cooley et al. 2001). Humans would be much less sensitive to peroxisome proliferation and thyroid hormone perturbation than rats and mice (European Commission 2000). There is adequate evidence for the carcinogenicity of SCCPs in rodents. Neoplastic effects were seen in the liver, thyroid and kidneys in rats and mice (Brucker-Davis 1998; Wyatt et al. 1993). However the dose-related increases in the incidence of adenomas and carcinomas observed in these organs are not relevant to human health, considering the likely underlying mechanisms for these tumors (European Commission 2000). Significant growth inhibitions and morphological malformations observed in our study could reflect possible effects of SCCPs on thyroid regulations affecting embryonic development but further research in this area is needed.

Surprisingly, the observed non-lethal embryotoxic effects of the tested compounds seem to be independent of chlorine content as both SCCP and n-dodecane induced qualitatively comparable effects (Fig. 1, Table 1). This observation is of particular interest as higher chlorination is traditionally linked to higher toxicity of organic compounds. Interestingly, also the study of Fisk et al. (1999) with medaka fish did not report significant differences in toxicities of SCCPs varying in the chain length and chlorine content. Only limited data exist on acute and chronic toxicities of non- 
chlorinated parent alkane, n-dodecane. In a study of Sice (1966), it was proposed to act as tumor promoter, possibly via peroxisome proliferation. Toxicological studies with structurally related n-alkanes showed effects on neural regulation (CNS depressants) or general irritation toxicity. Acute ecotoxicities $\left(48 \mathrm{~h} \mathrm{LC}_{50}\right)$ of n-octane and n-decane to Daphnia magna were 3.3 and $0.2 \mathrm{mg} / \mathrm{l}$, respectively (Irw in 1997) but we have observed only minor lethality at these concentrations after 96 hours. On the other hand, n-dodecane significantly induced developmental malformations and inhibited growth of frog embryos (Fig. 1, Table 1). Taken together, comparisons of our study with literature data indicate significant effects of both chlorinated and non-chlorinated aliphatic compounds to aquatic biota but further research is needed to fully understand consequences of possible chronic toxicities.

FETAX evaluating morphological malformations in frog embryos is an established and standardized assay (ASTM 1998). In our study we also assessed biochemical determination of GST activities as a biomarker of chronic stress (Livingstone 1998). SCCPs significantly induced GST after $96 \mathrm{~h}$ exposure and the modulations were observed at concentrations about an order of magnitude lower than those resulting in morphological alterations (Fig. 3). Although the embryonic development of Xenopus laevis is generally well understood, there is surprisingly limited information on profiles and activities of detoxification enzymes. Some recent studies focused on isolation and principal characterization phase II enzymes in Xenopus laevis (Angelucci et al. 2002), but to our best knowledge, biochemical responses in X. laevis embryos exposed to xenobiotics were not studied so far. Our study demonstrates good suitability of GST determination in FETAX as sensitive early warning parameter of chronic toxicities. Our results also correspond to the study of Brunstrom (1985) that described inductions of cytochromeP-450 (detoxification phase I enzymes) after 4 days exposures of chick embryos to SCCPs (C10-13, $\mathrm{Cl} 70 \%)$.

To evaluate environmental risks of SCCPs, no observable effect concentrations (NOECs) are often derived and compared with the environmental levels. In our study with Xenopus laevis embryos, experimental LOECs for SCCP (C-12, 56\% chlorine) were about $50 \mathrm{mg} / \mathrm{l}$ for morphological malformations and $0.5 \mathrm{mg} / 1$ for biochemical response (GST induction). Due to methodological limitations, there is only limited information on concentrations of SCCPs in the environmental compartments. Levels of SCCPs between $5-180 \mathrm{ng} / \mathrm{g}$ dry weight were recently reported in river sediments from the Czech Republic (Stejnarova et al. 2005), and these concentrations are within the range observed in Germany (<5 to $83 \mathrm{ng} / \mathrm{g}$, Balls chmiter 1994) or Canada (5.9 to $290 \mathrm{ng} / \mathrm{g}$ dry weight, Muir et al. 2000). However, concentrations of SCCPs as high as $448 \mathrm{ng} / \mathrm{l}$ were observed in sewage treatment plant effluents in Ontario, Canada, and the accumulation of SCCPs in the common carp up to $2.6 \mu \mathrm{g} / \mathrm{g}$ wet weight was documented (Muir et al. 2000). Although the NOEC values derived in our study with FETAX are above the actual concentrations found in the environment, other studies with aquatic organisms (Daphnia magna 21 day chronic $\mathrm{NOEC}=5 \mu \mathrm{g} / \mathrm{l}$, Tho mp s on and Madeley 1983a) indicate certain environmental hazards of SCCPs.

In conclusion, our study provides first experimental evidences on SCCPs- and dodecaneinduced morphological malformations in frog embryos. Suitability of GST assessment as early warning biomarker in FETAX was also demonstrated. Although the effects were observed in relatively high concentrations, the teratogenic index for SCCPs (TI > 10) indicates substantial embryotoxicity and teratogenic potential of SCCPs. With respect to high environmental persistency and bioaccumulation of these priority pollutants (EU Directive 2000/60/EC, Water Framework Directive), further research is needed to fully understand their chronic environmental hazards. 


\section{Subletální toxické efekty a indukce glutathion S-transferázy po expozici krátkořetězcovým chlorovaným parafínům a dodekanu v testu FETAX s embryi drápatky vodní (Xenopus laevis)}

Chlorované parafíny s krátkým řetězcem (SCCPs - Short Chain Chlorinated Paraffins) patř́i mezi významné průmyslové chemikálie s vysokou perzistencí v životním prostředí a bioakumulačním potenciálem, ale málo prostudovanou ekotoxicitou. V naší práci byly studovány neletální efekty komerční směsi SCCP (délka řetězce $\mathrm{C} 12$, procento chlorace $56 \%$, CP56-12) a nechlorované parentální látky (dodekan) v testu embryotoxicity a teratogenity s pulci drápatky Xenopus laevis (test FETAX - Frog Embryo Teratogenesis Assay - Xenopus). U obou hodnocených vzorků byla pozorována jen nízká letalita, která potvrdila malou akutní toxicitu těchto látek (v nejvyšší testované koncentraci $500 \mathrm{mg} / \mathrm{l}$ byla letalita $11 \%$ ). Na druhé straně byl zaznamenán významný nárůst v počtu vývojových defektů ve všech testovaných koncentracích (až 50 \% embryí s morfologickými malformacemi). Současně byla pozorována také inhibice růstu embryí. Naše výsledky prokazují významnou embryotoxicitu studovaných prioritních polutantů; účinek však nebyl závislý na stupni chlorace vzhledem k relativně srovnatelným výsledkům obou testovaných látek. Vedle klasických parametrů (mortalita, malformace) byl hodnocen také vliv chlorovaných parafínů na aktivitu detoxifikačního enzymu glutathion S-transferázy (GST). Byla zjištěna významná stimulace GST aktivity po expozici SCCP již v koncentracích $0.5 \mathrm{mg} / \mathrm{l}$. Ačkoliv efektivní toxické koncentrace chlorparafínů jsou vyšší než udávají informace o koncentracích v prostředí, významná bioakumulace a perzistence těchto látek může vést k negativním chronickým účinkům u vodních organismů.

\section{Acknowledgements}

Financial support from the Grant Agency of the Czech Republic (grant No. 525/03/0367) is highly acknowledged. The results are presented under the auspices of the EC Center of Excelence "RECETOX" (EVK12002-00519, http://www.recetox.muni.cz).

\section{References}

ANGELUCCI S, SACCHETTA P, DE LUCA A, MOIO P, AMICARELL, F, DI ILIO C 2002: Glutathione transferase isoenzymes from frog (Xenopus laevis) liver and embryo. BBA - Gen Subjects 1569: 81-85

ASTM 1998: American Society for Testing and Materials: Standard guide for conducting the Frog Embryo Teratogenesis Assay - Xenopus (FETAX). ASTM: E 1439-98

BALLSCHMITER K 1994: Bestimmung von kurtz- und mittelkettigen chloroparaffinen in Wasser- und Sedimentproben aus Oberflächenwässern. Universität Ulm. Abt. Analytische Chemie und Umweltchemie, 10 May, 1994

BENGTSSON BE, OFSTAD EB 1982: Long-term studies on uptake and elimination of some chlorinated paraffins in the bleak (Alburnus alburnus). Ambio 11: 38-40

BRUCKER-DAVIS F 1998: Effects of environmental synthetic chemicals on thyroid function. Thyroid 8: 827-855

BRUNSTROM B 1985: Effects of chlorinated paraffins on liver weight, cytochrome-P- 450 concentration and microsomal-enzyme activities in chick-embryos. Arch Toxicol 57: 69-71

CAMPBELL I, McCONNELL G 1980: Chlorinated paraffins and the environment.1. Environmental occurrence. Environ Sci Technol 14: 1209-1214

COOLEY HM, FISK AT, WIENS SC, TOMY GT, EVANS RE, MUIR DCG 2001: Examination of the behavior and liver and thyroid histology of juvenile rainbow trout (Oncorhynchus mykiss) exposed to high dietary concentrations of C-10-, C-11-, C-12- and C-14-polychlorinated n-alkanes. Aquat Toxicol 54: 81-99

DROUILLARD KG, TOMY GT, MUIR DCG, FRIESEN KJ 1998: Volatility of chlorinated n-alkanes (C10-C12): Vapor pressures and Henry s law constants. Environ Toxicol Chem 17: 1252-1260

DUMONT J, SCHULTZ T, BŪCHANAN M, KAO G 1983: Frog embryo teratogenesis assay: Xenopus (FETAX)A short-term assay applicable to complex environmental mixtures. In: WATERS M, SANDHU S, LEWTAS J, CLAXTON L, CHERNOFF N, NESNOW S (Eds): Short-term bioassays in the analysis of complex environmental mixtures III. Plenum Publishers, New York, pp. 393-405

EUROPEAN COMMISSION 2000: European Commission - Joint Research Centre. European Union Risk Assessment Report. Vol.4: alkanes, C10 - 13, chloro-. European Chemicals Bureau, Brussels, Belgium. 166 p. (EUR 19010; ISBN 92-828-8451-1)

FISK AT, CYMBALISTY CD, BERGMAN A, MUIR DCG 1996: Dietary accumulation of C-12- and C-16chlorinated alkanes by juvenile rainbow trout (Oncorhynchus mykiss). Environ Toxicol Chem 15: 1775-1782 
FISK AT, TOMY GT, MUIR DCG 1999: Toxicity of C-10-, C-11-, C-12-, and C-14-polychlorinated alkanes to Japanese medaka (Oryzias latipes) embryos. Environ Toxicol Chem 18: 2894-2902

GOVERNMENT OF CANADA 1993: Canadian Environmental Protection Act. Priority Substances List Assessment Report. Chlorinated Paraffins. Government of Canada, Environment Canada, Health and Welfare Canada

HABIG WH, PABST MJ, JAKOBI WB 1974: Glutathione S-transferases: the first enzymatic step in mercapturic acid formation. J Biol Chem 249: 7130-7139

HILL RW, MADDOCK BG 1983b: Effect of a chlorinated paraffin on embryos and larvae of the sheepshead minnow (Cyprinodon variegatus) - study 2. ICI Confidential report BL/B/2327

IRWIN RJ 1997: Environmental contaminants encyclopedia. Alkanes entry. National park service, Fort Collins, Colorado

KIESECKER JM, BLAUSTEIN AR, BELDEN LK 2001: Complex causes of amphibian population declines. Nature 410: 681-684

LINDEN E, BENGTSSON BE, SVANBERGO, SUNDSTROM G 1979: The acute toxicity of 78 chemicals and pesticide formulations against two brackish water organisms, the bleak (Alburnus alburnus) and the harpacticoid (Nitocra spinipes). Chemosphere 8: 843-851

LIVINGSTONE, DR 1998: The fate of organic xenobiotics in aquatic ecosystems: quantitative and qualitative differences in biotransformation by invertebrates and fish. Comp Biochem Phys A 120: 43-49

LOWRY OH, ROSEBROUGH AL, FARR AL, RANDALL RJ 1951: Protein measurements with Folin-Phenol reagents. J Biol Chem 193: 265-275

MADELEY JR, MADDOCK BG 1983a: Toxicity of a chlorinated paraffin over 60 days. (iv) Chlorinated paraffin - $58 \%$ chlorination of short chain length n-paraffins. ICI Confidential report BL/B/2291

MUIR DCG, BENNIE D, TEIXEIRA C, FISK AT, TOMY GT, STERN GA, WHITTLE M 2000: Short chain chlorinated paraffins: Are they persist and bioaccumulative? In: LIPNICK, R, JANSSON, B, MACKAY, D, PATREAS, M (Eds).:Persistent, bioaccumulative and toxic substances. Vol. 2. ACS Books, Washington, D.C., pp. 184-202

NIEUWKOOP PD, FABER J 1994: Normal Table of Xenopus laevis (Daudin). Garland, New York, NY

SICE J 1966: Tumor - promoting activity of n-alkanes and 1-alkanols. Toxicol Appl Pharm 9: 70-74

SPARLING DW, LINDER G, BISHOP CA 2000: Ecotoxicology of amphibians and reptiles, SETAC, ISBN 1880611-28-7

STREET JR, WINDEATT AJ, MADELEY JR 1983: Assessment of the ready biodegradability of a chlorinated paraffin by OECD method 301C. ICI Confidential report BL/B/2208

STEJNAROVA P, COELHAN M, KOSTRHOUNOVA R, PARLAR H, HOLOUBEK 2005: Analysis of short chain chlorinated paraffins in sediment samples from the Czech Republic by short-column GC/ECNI-MS. Chemosphere 58:253-262

THOMPSON RS, MADELEY JR 1983a: The acute and chronic toxicity of a chlorinated paraffin to Daphnia magna. ICI Confidential report $\mathrm{BL} / \mathrm{B} / 2358$

THOMPSON RS, MADELEY JR 1983d: The acute and chronic toxicity of a chlorinated paraffin to the mysid shrimp (Mysidopsis bahia). ICI Confidential report BL/B/2373

THOMPSON RS, SHILLABEER N 1983: Effect of a chlorinated paraffin on the growth of mussels (Mytilus edulis). ICI Confidential report $\mathrm{BL} / \mathrm{B} / 2331$

TOMY GT, FISK AT, WESTMORE JB, MUIR DCG 1998: Environmental chemistry and toxicology of polychlorinated n-alkanes. Rev Environ Contam T 158: $53-128$

TOMY GT, MUIR DCG, STERN GA, WESTMORE JB 2000: Levels of C-10-C-13 polychloro-n-alkanes in marine mammals from the Arctic and the St. Lawrence River estuary. Environ Sci Technol 34: 1615-1619

WYATT I, COUTTS CT, ELCOMBE CR 1993: The effect of chlorinated paraffins on hepatic-enzymes and thyroid-hormones. Toxicology 77: 81-90 
Plate VI

Burýšková B. et al.: Sublethal Toxic Effects ...pp. 115-122

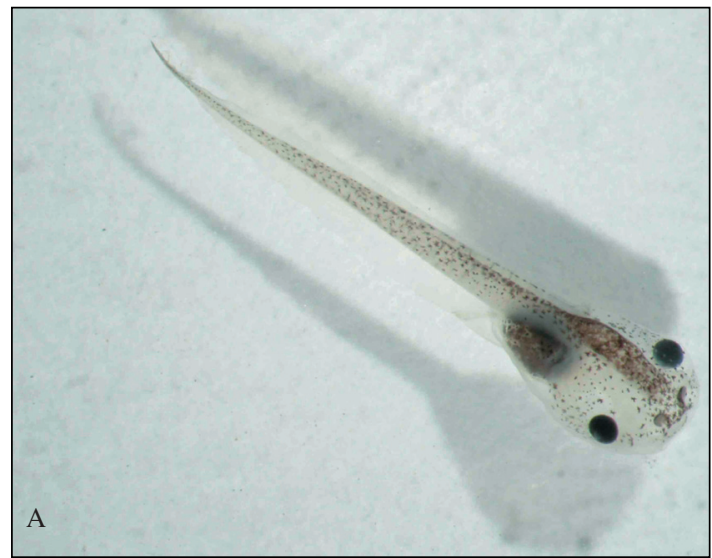

B
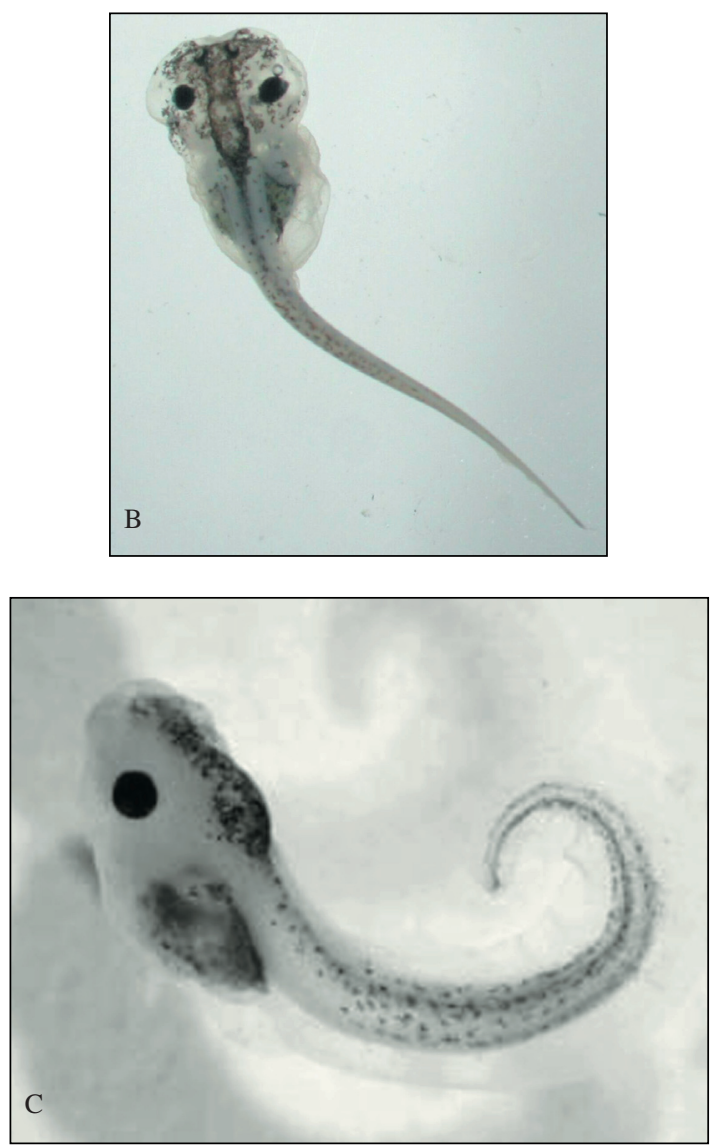

Fig. 2. Developmental malformations observed in Xenopus laevis embryos after 96 h exposure to commercial mixture of SCCP (CP56-12, Novácke Chemické závody).

A - control embryo, B - oedema and microphthalmia, C - skeletal malformation (adverse backbone curving) at SCCPs-exposed embryos 